\title{
NOTES
}

\section{HARASSMENT BY UNIONS AS A REFUSAL TO BARGAIN UNDER SECTION $8(b)(3)$ OF THE NLRA*}

Section 8 of the National Labor Relations Act imposes the duty of collective bargaining on management and labor. ${ }^{1}$ Section $8(\mathrm{~d})$ defines this duty as including the requirement that the parties "meet at reasonable times and confer in good faith" regarding wages, hours, or other conditions of employment, and "the negotiation of an agreement, or any question arising thereunder."2 Section 8(a) (5), a provision of the original NLRA, makes it an unfair labor practice for an employer to "refuse to bargain collectively with the representatives of his employees." 3 In order to equalize the responsibilities of collective bargaining, a Taft-Hartley Act amendment to the NLRA imposed a correlative duty on the union: section 8(b) (3) makes it an unfair labor practice for a labor organization to "refuse to bargain collectively with an employer." If the NLRB determines that either party has engaged in an unfair labor practice, section 10 (c) provides that the Board must issue an order requiring the offending party to "cease and desist" from this practice and to "take such affirmative action" as will effectuate the policies of the Act."

In cases where unions insisted on illegal contract terms such as the closed

*Textile Workers Union, CIO, and Personal Products Corp., 108 N.L.R.B. No. 109, 34 L.R.R.M. 1059 (May 5, 1954), petition for reviez filed, No. 12248 (D.C. Cir., May 27, 1954).

1. 61 Stat. 140 (1947), 29 U.S.C. $\$ 158$ (1952).

The original NLRA, the Wagner Act, was enacted by Congress in 1935. 49 SrAT. 449 (1935). In 1947, Title I of the Labor Management Relations Act, the Taft-Hartley Act, made extensive amendments to the NLRA. 61 STAT. 136 (1947). Unless otherwise specified, NLRA will refer to the amended Act.

2. 61 STAT. 142 (1947), 29 U.S.C. \$158(d) (1952).

3. 61 Stat. 141 (1947), 29 U.S.C. \& 158(a) (5) (1952). Under \& \&(a) (5), formarly $\S 8(5)$ of the original NLRA, the employer has been strictly held to the requirement of good faith in collective bargaining. See, e.g., H.J. Heinz Co. v. NLRB, 311 U.S. 514, 523-26 (1941) (refusal to sign contract) ; NLRB v. Boss Mfg. Co., 118 F.2d 187 (7th Cir. 1941) (mind "hermetically sealed" against reaching agreement). See H.R. REP. No. 245, 80th Cong., 1st Sess. 19-20 (1947).

4. 61 Stat. 141 (1947), 29 U.S.C. $\$ 158$ (b) (3) (1952).

The specific purpose of $\S 8$ (b) (3) was to make collective bargaining an obligation of the union as well as of the employer. See text at note 19 infra. Before the LMRA amendments, the NLRA had in some cases been interpreted as requiring, in effect, good faith bargaining by unions. See Times Publishing Co., 72 N.L.R.B. 676, 682-83 (1947) ; NLRl) v. Express Publishing Co., 128 F.2d 690, 692 (5th Cir.), cert. denicd, 317 U.S. 676 (1942).

The general purpose of the LMRA was to correct the alleged inequities in the treatment of employers under the NLRA, as contrasted with the alleged favoritism shown toward unions. See, generally, NLRB, LeG. HIST. LMRA (1948) ; Cox, Some Aspects of the Labor Management Relations Act, 1947, 61 HARv. L. REv. 1, 274 (1947-48).

5. 61 STAT. 147 (1947), 29 U.S.C. $\$ 160$ (c) (1952). Section 10(j) grants the NLRB power, after issuance of its complaint, to petition in a United States district court for temporary relief from an alleged unfair labor practice. 61 STAT. 149 (1947), 29 U.S.C. $\$ 160(j)$ (1952). Under $\$ 10(e)$, an NLRB order is enforceable in the federal courts upon petition by the Board. 61 STAT. 147 (1947), 29 U.S.C. $\$ 160$ (e) (1952). See, generally, Teller, The Taft-Hartley Act and "Govermment by Injunction", 35 VA. L. REv. 50 (1949). 
shop, ${ }^{6}$ or where they flatly refused to bargain ${ }^{7}$ or conditioned bargaining on employer concessions in advance, ${ }^{8}$ it has been uniformly held that the unions failed to fulfill their duty of good faith bargaining under section $S(b)(3)$, and appropriate remedial orders have issued. Moreover, in Plelps Dodge Copper Products Corp., ${ }^{9}$ the NLRB held that a union-sponsored slow-down during negotiations justified the employer's refusal to bargain further with the union. ${ }^{10}$ In the recent case of Personal Products Corp., ${ }^{11}$ the NLRB combined these two doctrines and held for the first time that it was an unfair labor practice under section $8(b)(3)$ for a union to engage in on-the-job harassment during a period of collective bargaining negotiations. 12

In Personal Products, the employer and union were negotiating for a new contract following expiration of the previous contract. ${ }^{13}$ After three months of unsuccessful bargaining, the union conmenced plant slowdowns and unannounced walkouts, refused to work overtime or special hours, extended rest periods without authority, and induced a subcontractor's employees not to work for the employer. ${ }^{14}$ The NLRB found that these devices were designed to "force the employer's hand" in the existing negotiations, and that they exerted "strong economic pressure" on the employer by interfering with production plans and delivery commitments. ${ }^{15}$ The Board stated that these "unprotected harassing tactics" were irreconcilable with the Act's requirement of "reasoned discussion in a background of balanced bargaining relations," constituted a refusal by the union to bargain in good faith under section $8(\mathrm{~b})(3){ }^{17}$ It ordered the union to cease and desist from the above tactics

6. National Maritime Union, 78 N.L.R.B. 971 (1948), enforicment granted, 175 F.2d 686 (2d Cir. 1949), cert. denied, 338 U.S. 954 (1950); Penello v. United Mrine Workers, S8 F. Supp. 935 (D.D.C. 1950); NLRB v. Puerto Rico S.S. Ass'n, 211 F.2d 274 (1st Cir. 1954).

7. Madden v. United Mine Workers, 79 F. Supp. 616 (D.D.C. 1948).

8. International Brotherhood of Teamsters, AFL, 87 N.L.R.B. 972, 978-79 (1949) (demand for performance bond) ; NLRB v. Retail Clerks Int'l Ass'n, AFL, 211 F.2d 759 (9th Cir.) (demand that employer bargain for supervisors), cert. denicd, 348 U.S. 839 (1954).

9. 101 N.L.R.B. 360 (1952).

10. Phelps Dodge Copper Products Corp., 101 N.L.R.B. 360, 368 (1952).

11. Textile Workers Union, CIO, and Personal Products Corp., 108 N.L.R.B. No. 109, 34 L.R.R.M. 1059 (Miay 5, 1954) (hereinafter referred to as Pcrsonal Products).

12. Id. at 6-7, 34 L.R.R.M. at 1063. One authority sees the possibility of "iar-reaching consequences" in the Personal Products application of $\$ \$(b)(3)$. Cox, Lacor Law 427 (3d ed. 1954).

13. Intermediate Report, p. 8, Textile Workers Union, CIO, and Personal Products Corp., 108 N.L.R.B. No. 109, 34 L.R.R.M. 1059, 1059-60 (May 5, 1954).

14. Textile Workers Union, CIO, and Personal Products Corp., 108 N.L.R.B. No. 109, p. 4, 34 L.R.R.M. 1059, 1062 (1íay 5, 1954). Each of these tacties is generally held unprotected, thus permitting the discharge of the participants. See cases cited note $30 \mathrm{infro}$.

15. Textile Workers Union, CIO, and Personal Products Corp., 108 N.L.R.B. No. 109, pp. 4-5, 34 L.R.R.MI. 1059, 1062 (May 5, 1954).

16. Id. at 5, 34 L.R.R.M. at 1062-63. The NLRB here was quoting Phelps Dodge Copper Products Corp., 101 N.L.R.B. 360 (1952).

17. Textile Workers Union, CIO, and Personal Products Corp., 10S N.L.R.B. No. 109, pp. 6-7, 34 L.R.R.M. 1059, 1063 (Jfay 5, 1954). 
and from "any similar or related conduct in derogation of the statutory duty to bargain."18

The NLRB justified its holding in Personal Products by referring to the clear congressional intent of section 8 (b) (3) to impose on unions the same duty to bargain in good faith which section 8(a) (5) had imposed on employers. ${ }^{19}$ Management's obligation to bargain in good faith has been extended to activities far removed from the bargaining table. Thus employers' antiunion threats and promises to employees have been held to be evidence of bad faith under section 8(a) (5), and appropriate remedial orders have issued.20 Personal Products similarly extends the union's obligation to bargain under section 8 (b) (3) by condemning union harassing tactics which, although they do not occur at the bargaining table, obstruct the bargaining process. ${ }^{21}$

The attitude of the Eightieth Congress toward the specific problem of harassment appears unclear. Section 12 of the House version of Taft-Hartley, a potpourri aimed at a large number of activities felt to be harmful to industrial peace, provided that a sit-down strike or "other concerted interference with an employer's operations conducted by remaining on the employer's premises" was subject to damage suit and injunction. ${ }^{22}$ The Senate-House Conference Committee deleted section $12 .^{23}$ However, this would not seem to indicate congressional intent to shield on-the-job harassment from NLRB remedial action, since the grounds for deletion were that many of the activities pro-

18. Id. at 9-10, 34 L.R.R.M. at 1065.

19. See statement of Senator Taft, 93 Cong. Rec. 3838 (1947), and Senator Ellender, id. at 4135. See also H.R. REp. No. 510, 80th Cong., 1st Sess. 43 (1947) ; National Maritime Union, 78 N.L.R.B. 971, 980-82 (1948), enforcenent granted, 175 F.2d 686 (2d Cir. 1949), cert. denied, 338 U.S. 954 (1950) ; Cox, Some Aspects of the Labor Management Relations Act, 1947, 61 Harv. L. Rev. 274, $282-83$ (1948).

The "good faith" requirement, now a part of $\S 8(\mathrm{~d})$, was nat in the original NLRA, but was read into the Act by the NLRB in the early cases. E.g., International Filter Co., 1.N.L.R.B. 489,498 (1936).

The Board in Personal Products noted that $\S 8(d)$ 's standards of good faith were applicable to unions as well as to employers. 108 N.L.R.B. No. 109, p. 3, 34 L.R.R.M. 1059, 1062 (May 5, 1954). See text at note 2 supra.

20. Great Southern Trucking Co. v. NLRB, 127 F.2d 180 (4th Cir.), ccrt. denied, 317 U.S. 652 (1942); Geigy Co., 99 N.L.R.B. 822 (1952), enforccment granted as modified, 211 F.2d 553 (9th Cir.), cert. denied, 348 U.S. 821 (1954). And see cases cited note 34 infra.

21. In addition to the harassing tactics in Personal Products, the doctrine of the case might be extended to other types of unprotected union action, such as refusal to handle struck goods, NLRB v. Montgomery Ward \& Co., 157 F.2d 486, 496-97 (8th Cir. 1946), refusal to obey company rules, Home Beneficial Life Ins. Co. v. NLRB, 159 F.2d 280 (4th Cir.), cert. denied, 332 U.S. 758 (1947), defamation of the employer, Jefferson Standard Broadcasting Co., 94 N.L.R.B. 1507 (1951), aff'd on other grouts sub nom. NLRB v. Local 1229, Int'1 Brotherhood of Electrical Workers, AFL, 346 U.S. 464 (1953), and attacks on the employer's property, NLRB v. Clinchfield Coal Corp., 145 F.2d 66, 71-73 (4th Cir. 1944).

22. H.R. 3020, 80th Cong., 1st Sess. $\$ 12$ (1947), 1 NLRB, LEg. Hist. LMRA 204 (1948).

23. H.R. ReP. No. 510, 80th Cong., 1st Sess. 58-59 (1947). 
scribed by this section were covered elsewhere in the Act and were unprotected under existing case law. ${ }^{24}$ And the broad equalizing aims of section $S(b)$ (3) imply that Congress intended to put an end to this disruptive union conduct. ${ }^{25}$

The union in Personal Products could have walked out on strike to enforce its bargaining demands without being accused of bad faith. ${ }^{20}$ Strikes to enforce bargaining demands constitute activity protected under the NLRA, and employers must reinstate all strikers except those whose positions have been filled or abolished during the strike. ${ }^{27}$ However, despite the fact that the NLRB at one time tended to look upon some types of on-the-job harassment during bargaining periods as not so indefensible as to justify discharge of the participating employees, ${ }^{28}$ more recent decisions have expressed the view that employees should not be allowed to continue to accept wages and at the same time disrupt production schedules by slowdowns, refusals to do certain types of work, or other insubordinate conduct.29 Because of this distinction, employers have been held to have the right to discharge employees engaging in these activities. ${ }^{30}$

24. Ibid. And see id. at $42-43$, for further discussion of $\$ 12$, indicating that the Conference Committee felt that many $\$ 12$ activities had been adequately covered by the conference agreement.

25. See text at note 19 supra. For congressional policy generally, see H.R. REP. No. 245, S0th Cong., 1st Sess. 3-6 (1947). In International Union, UAW v. Wisconsin Employment Relations Board, 336 U.S. 245 (1949) (hereinafter referred to as Briggs Strattonn), the Supreme Court, after discussing the legislative history of the LAIRA, held that harassment was subject to injunction under the Wisconsin Employment Peace Act, since Congress had not subjected it to NLRB control in the LAIRA. The Board in Personal Products distinguished Briggs Stratton on the grounds that the Supreme Court there had not been faced with a situation where the harassment obstructed good faith bargaining. Textile Workers Union, CIO, and Personal Products Corp., 10S N.L.R.B. No. 109, pp. 6-7, 34 L.R.R.M. 1059, 1063 (May 5, 1954).

26. See, generally, NLRB v. Pecheur Lozenge Co., 209 F.2d 393, 403-04 (2d Cir. 1953), cert. denied, 347 U.S. 953 (1954); Jeffery-DeWitt Insulator Co. v. NLRB, 91 F.2d 134, 140 (4th Cir.), cert. denied, 302 U.S. 731 (1937). Since no contract was in force between the parties, the provisions of $\S 8(d)$ requiring sixty days' notice prior to striking, would not seem to be applicable to such a strike. 61 SrAr. 142 (1947), 29 U.S.C. $\$ 158(d)(1952)$.

27. See NLRB v. Mackay Radio \& Telegraph Co., 304 U.S. 333, 346-47 (1938); NLRB v. United States Cold Storage Corp., 203 F.2d 924,927 (5th Cir.), cert. devicd, 346 U.S. 818 (1953). However, strikers who commit acts of violence usually need not be rehired. Local 3, United Packinghouse Workers, CIO v. NLRB, 210 F.2d 325, 331 (8th Cir.), cert. denied, 348 U.S. 822 (1954).

28. See Harnischfeger Corp., 9 N.L.R.B. 676, 685-87 (1938) (refusal to work overtime); Armour \& Co., 25 N.L.R.B. 989, 994-96 (1940) (brief slowdown).

29. See NLRB v. Montgomery Ward \& Co., 157 F.2d 486, 496-97 (8th Cir. 1946); C.G. Conn, Ltd. v. NLRB, 108 F.2d 390, 397-98 (7th Cir. 1939).

30. NLRB v. Fansteel Metallurgical Corp., 306 U.S. 240, 255-5S (1939); NLRB v. Miontgomery Ward \& Co., 157 F.2d 486, 496 (Sth Cir. 1946) ; Ell Lumber Co., 91 N.L.R.B. $333,337-38$ (1950). But where the unprotected activity was provoled by an employer's unfair labor practice, the employees, in some cases, have been reinstated. NLRB v. Elkland Leather Co., 114 F.2d 221, 225 (3d Cir.), cert. denicd, 311 U.S. 705 (1940). See generally' Cox, The Right to Engage in Concerted Activities, 26 Inv. L.J. 319 (1951) ; Note, 29 Ino. L.J. 284 (1954). 
Since the harassing in Personal Products occurred while the parties were actually bargaining, it might be reasoned that the decision holds no more than that harassment during a period of negotiation violates section $8(\mathrm{~b})(3)$. However, a broader reading of Personal Products seems justifiable. Harassment is almost always aimed at negotiation; its purpose is to coerce management into agreeing to change wages, hours, or working conditions. ${ }^{31}$ Bargaining sessions must be held in order to effectuate these desired changes. Because section 8 (d) imposes a continuous duty upon unions as well as employers to hold themselves ready to bargain on new issues or on the interpretation of existing contract terms, ${ }^{32}$ harassing, whenever practiced, might be viewed as contrary to the union's duty to confer in good faith with the employer. ${ }^{33}$ The fact that the union has failed to make a specific demand for negotiations should not lessen the employer's right to insist that it bargain in good faith. Holding that union harassment at any time is an unfair labor practice seems analogouts to the decisions holding that unilateral management action in making wage increases or changing hours or working conditions constitutes a refusal to bargain under section 8 (a) (5) even when the union has not requested collective bargaining on these issues. ${ }^{34}$

Where union harassment occurs during the term of a contract, more specific justification for applying section 8 (b) (3) may be found in the language of section $8(d)(4)$. This section provides that where there is a collective bargaining contract in effect, a union cannot strike "for a period of sixty days" after giving notice of proposed contract modifications "or until the expiration date of such contract, whichever occurs later." 35 It has been held a section 8 (d) (4) violation for a union to strike during the term of its contract. ${ }^{\text {so }}$ Since

31. International Union, UAW, AFL v. Wisconsin Employment Relations Board, 336 U.S. $245,248-50$ (1949).

32. NLRB v. Jacobs Mfg. Co., 196 F.2d 680, 683 (2d Cir. 1952) (new issues); § \&(d), 61 STAT. 142 (1947), 29 U.S.C. $\$ 158$ (d) (1952), quoted in text at note 2 supra (contract interpretation); NLRB v. Highland Shoe, Inc., 119 F.2d 218 (1st Cir. 1941) (same).

33. Union harassing would seem to be the antithesis of the good faith that $\$ 8(\mathrm{~d})$ expressly demands. See International Union, UAW, AFL v. Wisconsin Employment Relations Board, 336 U.S. 245, 249-50 (1949) ; Phelps Dodge Copper Products Corp., 101 N.L.R.B. 360, 368 (1952) ; Cox, supra note 30, at 338-39; Teller, A Labor Policy ror AMERICA 96 (1945).

34. May Dep't Stores Co. v. NLRB, 326 U.S. 376, 384-85 (1945) (wage increase); Krimm Lumber Co., 97 N.L.R.B. 1574, 1579 (1952), enforced, 203 F.2d 194 (2d Cïr. 1953) (same); Sullivan Dry Dock \& Repair Corp., 67 N.L.R.B. 627, 636-40 (1946) (bonus) ; cf. cases cited note 21 supra.

Where the union has requested collective bargaining on a proper subject, unilateral action clearly is a $\$ 8(\mathrm{a})(5)$ violation. Medo Photo Supply Corp. v. NLRB, 321 U.S. 678, 684 (1944) (wage increase) ; NLRB v. National Shoes, Inc., 208 F.2d 688, 692 (2d Cir. 1953) (same). See generally Cox \& Dunlop, Regulation of Collective Bargaining by the National Labor Relations Board, 63 Harv. L. Rev. 389, 395-96 (1950).

35. 61 Stat. 143 (1947), 29 U.S.C. \$158(d) (4) (1952).

36. Local 3, United Packinghouse Workers, CIO v. NLRB, 210 F.2d 325 (8th Cir.), cort. denied, 348 U.S. 822 (1954); cf. Lion Oil Co., 109 N.L.R.B. No. 106, 34 L.R.R.M. 1410 (Aug. 5, 1954). For general discussion of $\S 8(d)(4)$, see Note, 64 YALE L.J. 248 (1954). 
"strike" is defined in the Act as including "any concerted slow-down or other concerted interruption of operations by employees,"37 harassing tactics such as those occurring in Personal Products would seem to fall within the interdiction of section 8 (d) (4).38 Furthermore, since the employer has the option of turning union harassment into a technical strike by shutting down, he could thus bring harassment expressly under section $8(d)(4) .{ }^{39}$

An employer has the option of shutting down during a noncontract period, as well as when a contract is in force, when faced with harassment. However, in both these situations it seems more consonant with the NLRA's fundamental policy of minimizing the effect of industrial strife ${ }^{\text {t0 }}$ if the employer is permitted to restrain the activity under section $S(b)(3)$ rather than required to shut down in order to stop harassment..1 The employer could refrain from asking the NLRB to take action against harassment if he preferred to operate in the face of this conduct.

No amount of NLRB prohibition of union harassment will necessarily bring about the spirit of reasonableness during negotiations upon which collective bargaining depends. Moreover, the primary responsibility for collective bargaining must rest with management and labor rather than with the Board.92 However, the possibility of reasonable negotiations may be increased if the NLRB has power to restrain the most flagrant obstructions to good faith bargaining.

37. LMRA §501, 61 STAT. 161 (1947), 29 U.S.C. \$142 (1952). The legislative history of the LMRA is not clear as to whether $\$ 501$ definitions apply only to Titles II, III, \& IV, or also to Title I, which amended the NLRA. Compare Conference Report, H.R. Rep. No. 510, 80th Cong., 1st Sess. 68 (1947), with S. REP. No. 105, S0th Cong., 1st Sess. 30 (1947). The Supreme Court in Briggs Stratton, supra note 25, at 258, appeared to use $\S 501$ definitions in construing Title $I$.

While some courts have stated that harassment does not constitute a strike within the NLRA meaning. see, e.g., NLRB v. Montgomery Ward \& Co, 157 F.2d 486,497 (\&th Cir. 1946), the better approach is to consider harassment a strike, but to hold it unprotected, see International Union, UAW, AFL v. Wisconsin Employment Relations Board, 336 U.S. 245, 258-60 (1949) ; NLRB v. Fansteel Metallurgical Corp., 306 U.S. 240, 25457 (1939).

38. See text at note 14 sipra.

39. See International Shoe Co., 93 N.L.R.B. 907 (1951); Elk Lumber Co., 91 N.L.R.B. 333 (1950) ; C.G. Conn, Ltd. v. NLRB, 108 F.2d 390, 397 (1939). Such a strike would properly be termed an illegal strike allowing the employer to discharge the strilkers, rather than an economic strike, where he would be required to reinstate them. See text at note 27 supra. Prior to Personal Products, the only remedy for the harassed employer was a shutdown and mass discharge. See text at note 30 supra.

40. NLRA \$1, 61 Stat. 136 (1947), 29 U.S.C. \$151 (1952). Note especially paragraph four, which was added by the LMIRA amendments. And see LAIRA, Short Title and Declaration of Policy, \$1(b), 61 Stat. 136 (1947), 29 U.S.C. \$141(b) (1952); NLRB v. Fansteel Metallurgical Corp., 306 U.S. 240, 257-58 (1939).

41. Moreover, a shutdown may often prove unfeasible for the employer. See Note, 29 IXD. L.J. 284, $291-93$ (1954); cf. Note, 63 YALE L.J. 1186 (1954).

42. Cox \& Dunlop, Regulation of Collectize Bargainisg by the National Lator Relations Board, 63 HaRv. L. Rev. 389, 425-32 (1950). 